\title{
Article \\ Risk of Second Primary Thyroid Cancer in Women with Breast Cancer
}

\author{
Monika Cieszyńska ${ }^{1}$, Wojciech Kluźniak ${ }^{1}$, Dominika Wokołorczyk ${ }^{1}$, Cezary Cybulski ${ }^{1}$, Tomasz Huzarski ${ }^{1,2}$, \\ Jacek Gronwald ${ }^{1}$, Michał Falco ${ }^{3}$, Tadeusz Dębniak ${ }^{1}$, Anna Jakubowska ${ }^{1,4}$, Róża Derkacz ${ }^{1,5}$ (D) \\ Wojciech Marciniak ${ }^{1,5}{ }^{(\mathbb{D}}$, Marcin Lener ${ }^{1}$, Karolina Woronko ${ }^{1}$, Dominika Mocarz ${ }^{1}$, Piotr Baszuk ${ }^{1} \mathbb{D}$, \\ Marta Bryśkiewicz ${ }^{1}$, Steven A. Narod ${ }^{6}$ and Jan Lubiński ${ }^{1,5, *(\mathbb{D})}$
}

Citation: Cieszyńska, M.; Kluźniak, W.; Wokołorczyk, D.; Cybulski, C.;

Huzarski, T.; Gronwald, J.; Falco, M.; Dębniak, T.; Jakubowska, A.; Derkacz, R.; et al. Risk of Second Primary Thyroid Cancer in Women with Breast Cancer. Cancers 2022, 14, 957. https://doi.org/10.3390/ cancers14040957

Academic Editors: Gareth Evans, Emma Woodward, Judy Garber and Farrukh Aqil

Received: 3 December 2021

Accepted: 9 February 2022

Published: 15 February 2022

Publisher's Note: MDPI stays neutral with regard to jurisdictional claims in published maps and institutional affiliations.

Copyright: () 2022 by the authors. Licensee MDPI, Basel, Switzerland. This article is an open access article distributed under the terms and conditions of the Creative Commons Attribution (CC BY) license (https:// creativecommons.org/licenses/by/ $4.0 /)$.
1 International Hereditary Cancer Center, Department of Genetics and Pathology, Pomeranian Medical University, 71-252 Szczecin, Poland; monika.cieszynska@pum.edu.pl (M.C.); wojciech.kluzniak@pum.edu.pl (W.K.); dominika.wokolorczyk@pum.edu.pl (D.W.); cerazy.cybulski@pum.edu.pl (C.C.); tomasz.huzarski@pum.edu.pl (T.H.); jacek.gronwald@pum.edu.pl (J.G.); tadeusz.debniak@pum.edu.pl (T.D.); anna.jakubowska@pum.edu.pl (A.J.); roza.derkacz@read-gene.com (R.D.); wojciech.marciniak@read-gene.com (W.M.); marcin.lener@pum.edu.pl (M.L.); kw.woronko@wp.pl (K.W.); dm.mocarz@wp.pl (D.M.); piotr.baszuk@pum.edu.pl (P.B.); marta.bryskiewicz@pum.edu.pl (M.B.)

2 Department of Clinical Genetics and Pathology, University of Zielona Góra, 65-417 Zielona Góra, Poland

3 West Pomeranian Oncology Center, Radiation Oncology Department, 71-730 Szczecin, Poland; mfalco@onkologia.szczecin.pl

4 Independent Laboratory of Molecular Biology and Genetic Diagnostics, Pomeranian Medical University in Szczecin, 71-252 Szczecin, Poland

5 Read-Gene S.A., 72-003 Grzepnica, Poland

6 Women's College Research Institute, Women's College Hospital, Toronto, ON M5S 1B2, Canada; steven.narod@wchospital.ca

* Correspondence: lubinski@pum.edu.pl

Simple Summary: The goal of this study was to estimate the risk of thyroid cancer following a diagnosis of breast cancer and to identify (therapeutic and genetic) risk factors for the development of thyroid cancer after breast cancer. We followed 10,832 breast cancer patients for a mean of 14 years for new cases of thyroid cancer. Of the 10,832 women with breast cancer, 53 (0.49\%) developed a second case of primary thyroid cancer. The ten-year risk of thyroid cancer was higher in women who carried a CHEK2 mutation (1.5\%) than in women who carried no mutation $(0.9 \%)$. In Poland, following a diagnosis of breast cancer, the risk of thyroid cancer is increased four times, but is increased nine times in women who carry a CHEK2 mutation.

\begin{abstract}
The goal of this study was to estimate the risk of thyroid cancer following breast cancer and to identify therapeutic and genetic risk factors for the development of thyroid cancer after breast cancer. We followed 10,832 breast cancer patients for a mean of 14 years for new cases of thyroid cancer. All women were genotyped for three Polish founder mutations in BRCA1 (C61G, 4153delA, 5382insC) and four mutations in CHEK2 (1100delC, IVS2 + 1G/A, del5395, I157T). Information was collected on chemotherapy, radiotherapy, hormonal therapies, and oophorectomy. Of the 10,832 women, $53(0.49 \%)$ developed a second primary thyroid cancer. Based on Polish population statistics, the expected number was $12.4(\mathrm{SIR}=4.3)$. The ten-year risk of developing thyroid cancer was higher in women who carried a CHEK2 mutation (1.5\%) than in women who carried no mutation $(0.9 \%)$. The age-adjusted hazard ratio for developing thyroid cancer was $1.89(0.46-7.79 ; p=0.38)$ for those with a CHEK2 protein-truncating mutation and $2.75(1.29-5.85 ; p=0.009)$ for those with a CHEK2 missense mutation.
\end{abstract}

Keywords: thyroid cancer; breast cancer; CHEK2 


\section{Introduction}

The number of survivors of breast cancer is increasing worldwide due to wide-scale screening programs and effective therapies [1]. A diagnosis of breast cancer increases the risk of psychosocial distress, cardiovascular disease, and second primary cancers, including those of the contralateral breast, endometrium, ovary, colon, lung, and thyroid [2]. The risk of thyroid cancer increases approximately two-fold in breast cancer survivors [3,4]. Breast cancer is also the most common secondary malignancy among thyroid cancer patients [5].

Women with breast cancer are offered a range of therapies, including radiotherapy, chemotherapy, hormonal therapies (tamoxifen and aromatase inhibitors), and oophorectomy. It is not clear if any of these treatments impact the risk of thyroid cancer. The studies that have looked at radiotherapy conclude that the risk of thyroid cancer is not increased [6-8]. It is important to consider the risk of secondary primary cancers in the follow-up of breast cancer survivors and to identify those at the highest risk

The positive association between breast and thyroid cancers suggests a possible common genetic susceptibility in some cases. PTEN mutations predispose women to Cowden Syndrome (which features both thyroid cancer and breast cancers) [9]. CHEK2 is a tumor suppressor gene that participates in DNA repair, cell cycle arrest, and apoptosis in response to DNA damage. CHEK2 mutations are associated with cancers of the thyroid, breast, stomach, and prostate $[10,11]$. In addition, the missense variant I157T is associated with increased risks of colon cancer and kidney cancer [12,13]. Siolek et al. (2015) studied 468 unselected thyroid cancer patients for the presence of a CHEK2 mutation including 11 with a previous diagnosis of breast cancer [14]. Seven of the eleven patients (63\%) patients with both thyroid and breast cancer had a CHEK2 mutation, compared to $16 \%(73 / 468)$ of the thyroid cancer patients without breast cancer $(p<0.001)$. Approximately $6 \%$ of breast cancer patients in Poland carry a CHEK2 mutation. We have estimated that a CHEK2 mutation increases the risk of breast cancer by 2.5 times and the risk of thyroid cancer by 3.3 times $[14,15]$. Women with a BRCA1 mutation are at risk for a range of cancers other than breast cancer, but it has not been established that thyroid cancer is part of the BRCA1 cancer spectrum. It is the purpose of this paper to look at the combination of a history of breast cancer and a cancer-predisposing mutation on the subsequent risk of thyroid cancer.

\section{Materials and Methods}

\subsection{Study Subjects}

We enrolled 10,832 breast cancer patients from throughout Poland in the cohort study. Patients were diagnosed in oncology centers in Bialystok, Bielsko-Biala, Bydgoszcz, Gliwice, Kielce, Koszalin, Krakow, Lublin, Lodz, Olsztyn, Opole, Poznan, Rzeszow, Szczecin, Warszawa, Wroclaw, and Zielona Gora between 1996 and 2014. The clinical information collected included the age of diagnosis, year of breast cancer surgery, lymph node status, tumor size, histopathology, estrogen-receptor status, HER2 status, use of chemotherapy, radiotherapy, hormonal therapy, oophorectomy, and prior history of cancers. In some centers, only women diagnosed under age 50 were recruited (6755 women were diagnosed at or below age 50 and 4114 women with breast cancer diagnosed at or above age 50). Patients with a prior diagnosis of thyroid cancer were excluded from the current analysis (40 patients). All patients signed informed consent to use their blood samples for DNA analysis. The study was presented to the Ethics Committee of the Pomeranian Medical University in Szczecin, Poland, but the project did not require the Ethics Committee's approval.

\subsection{Laboratory Analyses}

The DNA of peripheral blood lymphocytes of patients was examined for the presence of four founder mutations in the CHEK2 gene, using standard molecular biology techniques. We genotyped three founder mutations in BRCA1 (C61G, 4153delA, 5382insC) using a multiplex-polymerase chain reaction (PCR) assay. These three founder BRCA1 mutations constituted $82 \%$ of all identified BRCA1-mutation carriers (303/370 patients) in a large series of 1018 Polish women with hereditary breast cancer who were fully sequenced [16]. 
The 5382insC mutation in exon 20 and the 4153delA mutation in exon 11 was detected using an allele-specific amplification PCR (ASA-PCR), and the third mutation (C61G), a substitution c.181T > G in exon 5 of BRCA1, was detected using restriction fragment length polymorphism PCR (RFLP-PCR) using Ava II enzyme, using methods described in detail previously.

We also genotyped the four most frequent CHEK2 mutations in the Polish population: Three protein-truncating mutations (1100delC, IVS2 + 1G > A, del5395) and one missense mutation (I157T), which is a missense substitution of an isoleucine for threonine in exon 3 [12]. In a study of 390 Polish men with familial prostate cancer, three founder CHEK2 mutations (1100delC, IVS2 + 1G > A, I157T) constituted 100\% (39/39 carriers) of all identified CHEK2- truncating or missense mutations [17]. In the current study, we also genotyped for a founder large deletion of exon 9 and 10 of CHEK2, which is present with a frequency of $0.4 \%$ in Poland. We are not aware of the presence of other reccurrent $\mathrm{CHEK} 2$ large deletions in Poland. Three mutations in CHEK2 including 1100delC (c.1100delC), IVS2 + 1G > A (c.444 + 1G > A), and I157T (c.470T > C) were genotyped using TaqMan assay (Thermo Fisher Scientific, Waltham, MA, USA) using the LightCycler ${ }^{\circledR}$ Real-Time PCR 480 System (Roche Life Science, Penzberg, Germany). The 1100del C mutation was detected using the forward primer Chk2delC_F GGCAGACTATGTTAATCTTTTTATTTTATGG, the reverse primer Chk2delC_R CAAGAACTTCAGGCGCCAAGT, and two probes: Chk2delC HEX-TTTAGATTACTGATTTTGGGC-BHQ1 and Chk2wt 6-FAM- TTAGATTATGATTTTGGGCAC-BHQ1. The IVS2 + 1G > A mutation was analyzed using the forward primer Chek2_IVS_F ACCGAACATACAGCAAGAAACACTT, the reverse primer Chek2_IVS_R TGACCAAATTACCAGCTCTCCTAGA, and two probes: Chek2_IVS_M HEX-CGGATTTTCAGGATAGGTA-NFQ and Chek2_IVS_wt 6FAM-TCGGATTTTCAGGGTAGGTA-NFQ. The I157T missense variant was detected using the forward primer Chek2_Mis_F TGTTCTCTATTTTAGGAAGTGGGTCCT, the reverse primer Chek2_Mis_R AAGGTTCCATTGCCACTGTGAT, and two probes Chek2_Mis_M HEX-CTTCTATGTATGCAATGTAAG-BHQ1 and Chek2_Mis_WT 6-FAM-CTTCTATGTAT GCAGTGTAAG-BHQ1. The large deletion of exon 9 and 10 of the CHEK2 gene was genotyped using the multiplex-PCR reaction. In detail, two primer pairs were designed specifically for genotyping a large deletion of exons 9 and 10 in a multiplex PCR. The first pair (CHLdel2F TGTAATGAGCTGAGATTGTGC, CHLc2R CAGAAATGAGACAGGAAGTT) flanked the breakpoint site in intron 8. The second pair (CHLdelR GTCTCAAACTTGGCTGCG, CHLcF CTCTGTTGTGTACAAGTGAC) flanked the breakpoint site in intron 10. In mutation-negative cases, only two PCR fragments of 379 and 522 bp were amplified from the wild-type allele. The forward primer of the first pair and the reverse primer of the second pair amplified an additional PCR product of $450 \mathrm{bp}$ in deletion-positive cases.

\subsection{Statistical Analysis}

Patients were followed from the date of diagnosis until the first instance of thyroid cancer, death from any cause, or date of last follow up. The annual risk of thyroid cancer was calculated as the ratio of thyroid cancer events to the total person-years of follow-up. We compared the observed number of thyroid cancers to the expected number of thyroid cancer cases using data from female age-specific thyroid cancer incidence rates in Poland.

The 10- year actuarial risk of thyroid cancer was calculated using the Kaplan-Meier method. In a multivariable model, we estimated the adjusted hazard ratios for the development of thyroid cancer according to the age of diagnosis and treatments received (radiotherapy, chemotherapy, tamoxifen, and oophorectomy). Oophorectomy was modeled as a time-dependent variable. We also included the presence of a CHEK2 mutation and a BRCA1 mutation in the Cox proportional hazards model.

\section{Results}

Among 10,792 breast cancer patients, 53 patients $(0.48 \%)$ developed thyroid cancer in the follow-up period. The majority of thyroid cancers were papillary carcinomas (45), but 
there were also three cases of follicular and two cases of medullary carcinoma (for $6 \%$ of cases the pathological type was missing). The median time from breast cancer diagnosis to thyroid cancer diagnosis was 6.3 years. The characteristics of the women with and without thyroid cancer are presented in Table 1.

Table 1. Comparison of subjects with or without thyroid cancer after breast cancer.

\begin{tabular}{|c|c|c|c|}
\hline Variables & $\begin{array}{l}\text { No Thyroid Cancer } \\
n=10,739\end{array}$ & $\begin{array}{l}\text { Had Thyroid Cancer } \\
n=53\end{array}$ & $p$-Value \\
\hline Year of birth & 1955.6 (1918-1993) & $1956.6(1933-78)$ & 0.48 \\
\hline Age at diagnosis & $51.2(18-92)$ & $49.1(31-75)$ & 0.17 \\
\hline Year of diagnosis & 2006.9 (1988-2014) & 2005.7 (1996-2012) & 0.05 \\
\hline $\begin{array}{l}\text { Age at thyroid cancer } \\
\text { Years from breast cancer to } \\
\text { thyroid cancer }\end{array}$ & & $\begin{array}{l}55.5(35-84) \\
6.3(1-17)\end{array}$ & \\
\hline $\begin{array}{l}\text { ER status } \\
\text { positive } \\
\text { negative } \\
\text { missing }\end{array}$ & $\begin{array}{l}5878(67.5) \\
2825(32.5) \\
1672\end{array}$ & $\begin{array}{l}33(70.2) \\
14(29.8) \\
7\end{array}$ & 0.70 \\
\hline $\begin{array}{l}\text { Her2 status } \\
\text { Positive } \\
\text { Negative } \\
\text { Missing }\end{array}$ & $\begin{array}{l}1239(17.3) \\
5929(82.7) \\
3571\end{array}$ & $\begin{array}{l}4(11.1) \\
32(88.9) \\
17\end{array}$ & 0.75 \\
\hline $\begin{array}{l}\text { Tumor Size } \\
<2 \mathrm{~cm} \\
>2 \mathrm{~cm}\end{array}$ & $\begin{array}{l}4251(50.6) \\
4143(49.4)\end{array}$ & $\begin{array}{l}30(66.7) \\
15(33.3)\end{array}$ & 0.03 \\
\hline $\begin{array}{l}\text { Nodes } \\
\text { Positive } \\
\text { Negative }\end{array}$ & $\begin{array}{l}3899(44.6) \\
4842(55.4)\end{array}$ & $\begin{array}{l}10(21.7) \\
36(78.3)\end{array}$ & 0.002 \\
\hline $\begin{array}{l}\text { Chemotherapy } \\
\text { yes } \\
\text { no }\end{array}$ & $\begin{array}{l}5953(62.2) \\
3611(37.8) \\
\end{array}$ & $\begin{array}{l}27(56.3) \\
21(43.8)\end{array}$ & 0.39 \\
\hline $\begin{array}{l}\text { Radiotherapy } \\
\text { yes } \\
\text { no }\end{array}$ & $\begin{array}{l}4574(59.2) \\
3158(40.8)\end{array}$ & $\begin{array}{l}25(53.2) \\
22(46.8)\end{array}$ & 0.41 \\
\hline $\begin{array}{l}\text { Tamoxifen } \\
\text { yes } \\
\text { no }\end{array}$ & $\begin{array}{l}6175(68.1) \\
2892(31.9)\end{array}$ & $\begin{array}{l}37(77.1) \\
11(22.9)\end{array}$ & 0.18 \\
\hline $\begin{array}{l}\text { CHEK2 mutation } \\
\text { No } \\
\text { Yes }\end{array}$ & $\begin{array}{l}9835(91.6) \\
904(8.4)\end{array}$ & $\begin{array}{l}43(81.1) \\
10(18.9)\end{array}$ & 0.006 \\
\hline $\begin{array}{l}\text { BRCA1 mutation } \\
\text { No } \\
\text { Yes }\end{array}$ & $\begin{array}{l}10,220(95.3) \\
502(4.7)\end{array}$ & $\begin{array}{l}50(98.0) \\
1(2.0)\end{array}$ & 0.36 \\
\hline
\end{tabular}

The annual rate of thyroid cancer in the cohort was 54 per 100,000 per year (Table 2) Based on the age-specific annual incidence rates of thyroid cancer in the Polish population, the expected number of thyroid cancers was $12.4(\mathrm{SIR}=4.27)$. 
Table 2. Annual rates of thyroid cancer in the cohort.

\begin{tabular}{llllll}
\hline & & \multicolumn{2}{c}{ Thyroid Cancer Patients } & \multicolumn{2}{l}{$\begin{array}{l}\text { Poland General Population (Female) } \\
\text { Per 100,000 Per Year }\end{array}$} \\
\cline { 3 - 5 } & Cases Observed & Person Years & $\begin{array}{l}\text { Annual Risk Per } \\
\mathbf{1 0 0 , 0 0 0} \text { Per Year }\end{array}$ & $\begin{array}{l}\text { Annual Risk } \\
\text { (Poland) }\end{array}$ & Cases Expected \\
\hline $35-40$ & 4 & 3531 & 113.2 & 9.8 & 0.34 \\
$40-44$ & 3 & 8461 & 35.4 & 8.6 & 0.72 \\
$45-49$ & 5 & 17,812 & 39.2 & 12.5 & 2.22 \\
$50-54$ & 15 & 24,196 & 70.2 & 12.5 & 3.02 \\
$55-59$ & 8 & 20,175 & 39.6 & 14.3 & 2.88 \\
$60-64$ & 9 & 12,389 & 72.6 & 16.8 & 2.20 \\
$65-70$ & 6 & 6067 & 98.9 & & 1.02 \\
\hline
\end{tabular}

Moreover, 914 breast cancer patients (8.3\%) carried a CHEK2 mutation (659 missense mutations and 255 protein-truncating mutations (47 1100delC; 91 IVS2 + 1G/A and 117 del5395 mutations) and 502 breast cancer patients (4.6\%) carried a BRCA1 mutation.

Among the 914 women with a CHEK2 mutation, there were 10 thyroid cancers observed, versus 1.04 expected $(\mathrm{SIR}=8.7)$. Eight of the CHEK2 mutations were missense and two were truncating. The annual risk of thyroid cancer was 114 per 100,000 per year in those with a CHEK2 mutation (Table 3). The cumulative incidence of thyroid cancer in those with and without a CHEK2 mutation is presented in Figure 1. Among the women with a BRCA1 mutation there was only one case of thyroid cancer observed; however, this woman also carried a CHEK2 mutation.

Table 3. Annual rates of thyroid cancer, CHEK2 carriers only.

\begin{tabular}{|c|c|c|c|c|c|}
\hline \multirow[b]{2}{*}{ Age Group } & \multicolumn{3}{|c|}{ Thyroid Cancer Patients } & \multicolumn{2}{|c|}{$\begin{array}{l}\text { Poland general Population (Female) } \\
\text { Per 100,000 Per Year }\end{array}$} \\
\hline & Number of Events & Person Years & $\begin{array}{l}\text { Annual Risk Per } \\
\text { 100,000 Per Year }\end{array}$ & $\begin{array}{l}\text { Annual Risk } \\
\text { (Poland) }\end{array}$ & Cases Expected \\
\hline $35-40$ & 1 & 298 & 335 & 9.8 & 0.03 \\
\hline $40-44$ & 0 & 735 & 0 & 8.6 & 0.06 \\
\hline $45-49$ & 1 & 1538 & 65.0 & 12.5 & 0.19 \\
\hline $50-54$ & 2 & 2067 & 96.8 & 12.5 & 0.26 \\
\hline $55-59$ & 2 & 1692 & 118 & 14.3 & 0.24 \\
\hline $60-64$ & 1 & 1034 & 96.7 & 17.8 & 0.18 \\
\hline $65-70$ & 2 & 489 & 409 & 16.8 & 0.08 \\
\hline
\end{tabular}

The univariable and multivariable hazard ratios for the development of thyroid cancer are presented in Table 4 . The age-adjusted hazard ratio for developing thyroid cancer was $1.89(0.46-7.79 ; p=0.38)$ for those with a CHEK2 protein-truncating mutation and was $2.75(1.29-5.85 ; p=0.009)$ for those with a CHEK2 missense mutation. We did not see an increase in the risk of thyroid cancer associated with radiotherapy. We saw a borderline significant decrease in the risk of thyroid cancer associated with prior chemotherapy $(\mathrm{HR}=0.52(0.28-0.97) ; p=0.04)$. 


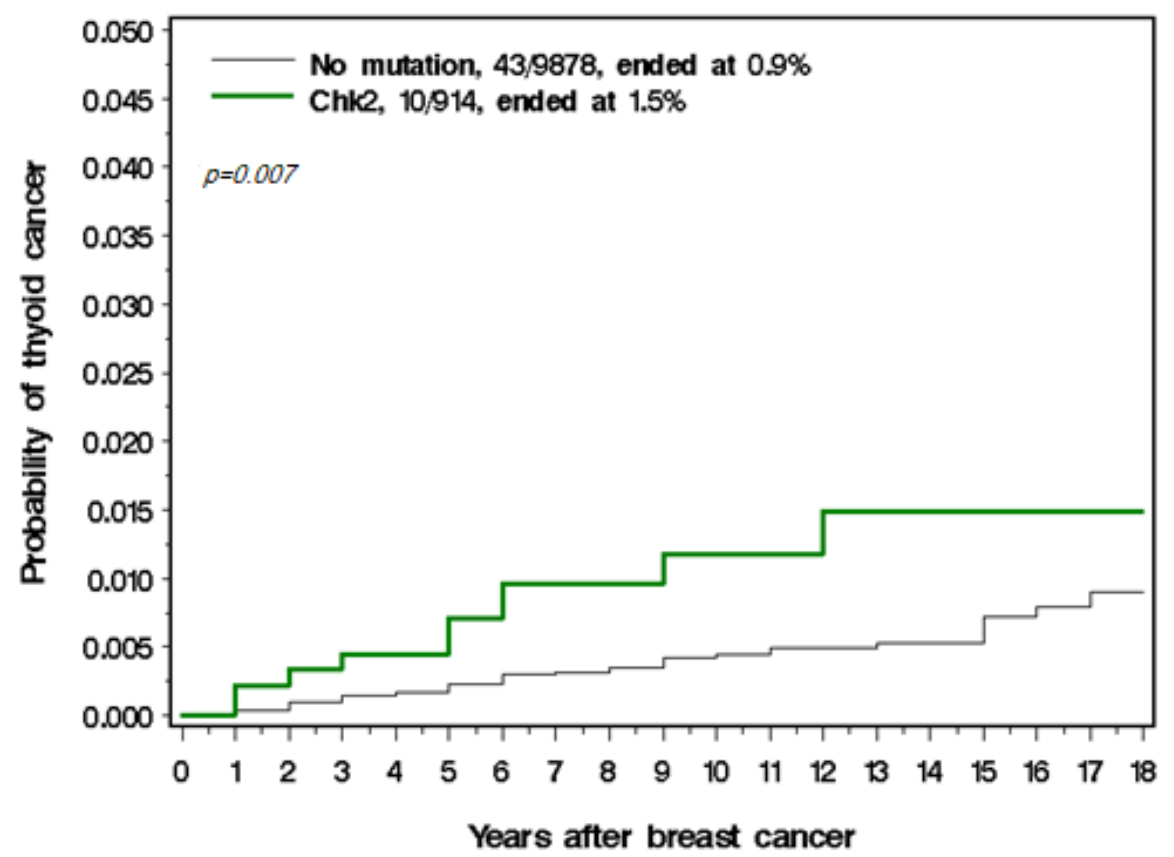

Figure 1. Cumulative incidence of thyroid cancer in those with and without a CHEK2 mutation.

Table 4. Hazard ratios for thyroid cancer after breast cancer, selected variables.

\begin{tabular}{|c|c|c|c|}
\hline Variables & Control/Case & $\begin{array}{l}\text { Univariate } \\
\text { HR(95\%CI)P }\end{array}$ & $\begin{array}{l}\text { Multivariate } \\
\text { HR(95\%CI)P }\end{array}$ \\
\hline \multicolumn{4}{|c|}{ Age at breast cancer diagnosis } \\
\hline$<45$ & $3419 / 17$ & 1 & 1 \\
\hline $45-50$ & $3253 / 22$ & $1.32(0.70-2.49) 0.38$ & $1.24(0.66-2.35) 0.51$ \\
\hline $50-65$ & $2687 / 11$ & $1.31(0.60-2.88) 0.50$ & $1.00(0.44-2.27) 1.00$ \\
\hline$>65$ & $1308 / 3$ & $0.77(0.22-2.68) 0.68$ & $0.50(0.14-1.81) 0.29$ \\
\hline ER-negative & $2825 / 14$ & 1 & \\
\hline ER-positive & $5878 / 33$ & $1.18(0.63-2.20) 0.61$ & \\
\hline \multirow{2}{*}{$\begin{array}{l}\text { Her2 negative } \\
\text { Her2 positive }\end{array}$} & $5029 / 32$ & 1 & \\
\hline & $\begin{array}{l}5929 / 32 \\
1239 / 4\end{array}$ & $0.58(0.18-1.92) 0.37$ & \\
\hline \multicolumn{4}{|l|}{ BRCA1 } \\
\hline No & $10,220 / 50$ & 1 & 1 \\
\hline Yes & $502 / 1$ & $0.38(0.05-2.72) 0.33$ & $0.39(0.05-2.99) 0.37$ \\
\hline \multicolumn{4}{|l|}{ CHEK2 } \\
\hline No & $9835 / 43$ & 1 & 1 \\
\hline Yes & $904 / 10$ & $2.52(1.27-5.01) 0.009$ & $2.17(1.08-4.37) 0.03$ \\
\hline Yes, truncating & $242 / 2$ & $1.89(0.46-7.79) 0.38$ & $1.68(0.40-7.04) 0.48$ \\
\hline Yes, missense & $662 / 8$ & $2.75(1.29-5.85) 0.009$ & $2.24(1.09-5.01) 0.03$ \\
\hline \multicolumn{4}{|l|}{ Chemotherapy } \\
\hline No & $3611 / 21$ & 1 & 1 \\
\hline Yes & $5953 / 27$ & $0.70(0.40-1.25) 0.23$ & $0.52(0.28-0.97) 0.04$ \\
\hline \multicolumn{4}{|l|}{ Radiotherapy } \\
\hline No & $3158 / 22$ & 1 & 1 \\
\hline Yes & $4572 / 25$ & $0.91(0.50-1.62) 0.76$ & $0.96(0.53-1.72) 0.88$ \\
\hline \multicolumn{4}{|l|}{ Tamoxifen } \\
\hline No & $2897 / 11$ & 1 & 1 \\
\hline Yes & $6175 / 37$ & $1.60(0.82-3.15) 0.17$ & $1.40(0.70-2.79) 0.34$ \\
\hline \multicolumn{4}{|l|}{ Oophorectomy } \\
\hline No & $7539 / 37$ & 1 & 1 \\
\hline Yes & $1162 / 10$ & $1.40(0.48-1.65) 0.71$ & $1.33(0.61-2.93) 0.48$ \\
\hline
\end{tabular}

Oophorectomy was used as a time-dependent variable; in the univariate analyses, missing data on oophorectomy were excluded and in the multivariate analyses the missing data were included in the no-oophorectomy group so that all 10,792 subjects were used in the multivariate regression. Because of collinearity, we did not include ER status or HERs status in the multivariate model. 


\section{Discussion}

In this large cohort study, we estimated the risk of thyroid cancer in women with a previous diagnosis of breast cancer. There were 53 new cases of thyroid cancer in the cohort for an average annual risk of $0.5 \%$ per year. The risk did not vary by age of diagnosis or by attained age. Based on the Polish National Cancer Registry, the expected number of thyroid cancer cases was $12.4(\mathrm{SIR}=4.3)$ [18]). Previous studies indicated that breast cancer patients have an approximately two-fold increased risk of thyroid cancer [3; 4]. In Asian populations, the frequency of thyroid cancer after breast cancer is higher (SIR $=4.75)[19,20]$.

In our cohort, the most significant predictor of thyroid cancer was the presence of a CHEK2 mutation. In our study, 10 of 914 CHEK2 mutation carriers developed thyroid cancer $(\mathrm{HR}=2.52 ; 95 \% 1.27-5.01 ; p=0.009)$. Overall, 10 of the 53 cases of second primary thyroid cancer $(19 \%)$ could be attributed to carrying a CHEK2 mutation. We have previously estimated that a CHEK2 mutation increases the risk of thyroid cancer by 3.3 times over the general population [14]. Among women with a CHEK2 mutation and breast cancer, the relative risk increases from three-fold to nine-fold.

It is not clear what other factors are responsible for the increase in the risk of thyroid cancer in breast cancer patients, but these might include other genes, treatment factors, and lifestyle factors. We did not test for the presence of mutations in genes other than BRCA1 and CHEK2. It is possible that the genetic background (e.g., SNPs) that predispose CHEK2 carriers to breast cancer also predispose them to thyroid cancer.

We did not see an increase in the risk of thyroid cancer in our cohort associated with radiotherapy, consistent with previous studies [6-8]. We saw a borderline decrease in the risk of thyroid cancer associated with previous chemotherapy. The data are few but this observation suggests that chemotherapy does not contribute to the increased risk of thyroid cancer. The association deserves further study. In summary, the increase in thyroid cancer risk does not seem to be due to treatment factors.

It has been suggested that lifestyle factors and environmental factors might contribute to the risk of thyroid cancer among breast cancer patients [21]. Proposed factors include obesity and exposure to endocrine disruptors. In our study, the probability of developing thyroid cancer was similar for those who were ER-positive and those who were ER-negative, and the use of tamoxifen did not reduce the risk of thyroid cancer (Table 4). We did not have information on other risk factors for thyroid cancer such as BMI or lifestyle factors.

There are several other limitations to this study. We assumed that all thyroid cancers were independent cancers (and not breast cancer metastases). We did not have details on the clinical presentation of thyroid cancers nor the treatments they received. For a substantial proportion of women, data on ER and HER2 were missing. We sought founder mutations only, as these account for greater than $80 \%$ of the BRCA1 and CHEK2 mutations in the Polish population, but we may have missed a number of mutation carriers [16,17]. It was not practical to perform full gene sequencing on the entire cohort of 10,000 patients.

These results suggest that screening for thyroid cancer among breast cancer patients with a CHEK2 mutation might be warranted. Routine thyroid ultrasonography detects thyroid nodules in $8 \%$ of breast cancer patients [22,23]. It is not clear if thyroid cancer screening reduces mortality (which is low), and issues of over-diagnosis have been raised. Further, the risk of thyroid cancers in the CHEK 2 carriers was only $1.5 \%$ over ten years.

\section{Conclusions}

The risk of thyroid cancer in women with a (truncating or missense) mutation in CHEK2 is approximately nine times that of the general population of Poland. Approximately $19 \%$ of thyroid cancers after breast cancer are attributable to CHEK2 mutations. 
Author Contributions: Conceptualization, M.C., J.L., S.A.N., C.C., T.H., J.G., T.D. and A.J.; methodology, M.C., W.K., D.W., C.C., K.W. and D.M.; validation, W.K., D.W., M.F., R.D., W.M., K.W. and D.M.; formal analysis, P.B. and M.B.; investigation, M.C., W.K., R.D., W.M., K.W. and D.M.; resources, M.C., W.K., D.W., C.C., T.H., J.G., M.F., T.D., A.J., R.D., W.M., M.L., P.B., M.B., S.A.N. and J.L.; data curation, P.B. and M.B.; writing-original draft preparation, M.C., S.A.N. and J.L.; writing-review and editing, M.C., W.K., D.W., C.C., T.H., J.G., M.F., T.D., A.J., R.D., W.M., M.L., P.B., M.B., K.W., D.M., S.A.N. and J.L.; visualization, M.C., M.L.; supervision, J.L.; project administration, T.H., J.G., T.D., A.J., M.F. and M.L. All authors have read and agreed to the published version of the manuscript.

Funding: This research received no external funding.

Institutional Review Board Statement: The study was conducted according to the guidelines of the Declaration of Helsinki. The study was presented to the Ethics Committee of the Pomeranian Medical University in Szczecin, Poland, but the project did not require the Ethics Committee's approval.

Informed Consent Statement: Informed consent was obtained from all subjects involved in the study.

Data Availability Statement: The datasets used and/or analyzed during the current study are available from the corresponding author on reasonable request.

Acknowledgments: The authors give their thanks for support to Breast Cancer Campaign Estée Lauder Companies.

Conflicts of Interest: The authors declare no conflict of interest.

\section{References}

1. Breast Cancer: Statistics. Available online: https://www.cancer.net/cancer-types/breast-cancer/statistics (accessed on 23 October 2021).

2. Joseph, K.R.; Edirimanne, S.; Eslick, G.D. The association between breast cancer and thyroid cancer: A meta-analysis. Breast Cancer Res. Treat. 2015, 152, 173-181. [CrossRef] [PubMed]

3. Nielsen, S.M.; White, M.; Hong, S.; Aschebrook-Kilfoy, B.; Kaplan, E.L.; Angelos, P.; Kulkarni, S.A.; Olopade, O.I.; Grogan, R.H. The Breast-Thyroid Cancer Link: A Systematic Review and Meta-analysis. Cancer Epidemiol. Biomark. Prev. 2016, 25, 231-238. [CrossRef] [PubMed]

4. Li, C.I.; Rossing, M.A.; Voigt, L.F.; Daling, J.R. Multiple primary breast and thyroid cancers: Role of age at diagnosis and cancer treatments (United States). Cancer Causes Control 2000, 11, 805-811. [CrossRef] [PubMed]

5. Zafon, C.; Obiols, G.; Mesa, J. Second primary cancer in patients with papillary thyroid carcinoma. Anticancer Res. 2013, 33, 337-340. [PubMed]

6. Grantzau, T.; Overgaard, J. Risk of second non-breast cancer after radiotherapy for breast cancer: A systematic review and meta-analysis of 762,468 patients. Radiother. Oncol. 2015, 114, 56-65. [CrossRef] [PubMed]

7. Huang, J.; Walker, R.; Groome, P.G.; Shelley, W.; MacKillop, W.J. Risk of thyroid carcinoma in a female population after radiotherapy for breast carcinoma. Cancer 2001, 92, 1411-1418. [CrossRef]

8. Sun, L.-M.; Lin, C.-L.; Liang, J.-A.; Huang, W.-S.; Kao, C.-H. Radiotherapy did not increase thyroid cancer risk among women with breast cancer: A nationwide population-based cohort study. Int. J. Cancer 2015, 137, 2896-2903. [CrossRef]

9. Yehia, L.; Keel, E.; Eng, C. The Clinical Spectrum of PTEN Mutations. Annu. Rev. Med. 2020, 71, 103-116. [CrossRef]

10. Cybulski, C.; Górski, B.; Huzarski, T.; Masojć, B.; Mierzejewski, M.; Dębniak, T.; Teodorczyk, U.; Byrski, T.; Gronwald, J.; Matyjasik, J.; et al. CHEK2 Is a Multiorgan Cancer Susceptibility Gene. Am. J. Hum. Genet. 2004, 75, 1131-1135. [CrossRef]

11. Teodorczyk, U.; Cybulski, C.; Wokołorczyk, D.; Jakubowska, A.; Starzyńska, T.; Ławniczak, M.; Domagala, P.; Ferenc, K.; Marlicz, K.; Banaszkiewicz, Z.; et al. The risk of gastric cancer in carriers of CHEK2 mutations. Fam. Cancer 2013, 12, 473-478. [CrossRef]

12. Cybulski, C.; Wokołorczyk, D.; Kładny, J.; Kurzawski, G.; Suchy, J.; Grabowska, E.; Gronwald, J.; Huzarski, T.; Byrski, T.; Górski, B.; et al. Germline CHEK2 mutations and colorectal cancer risk: Different effects of a missense and truncating mutations? Eur. J. Hum. Genet. 2007, 15, 237-241. [CrossRef] [PubMed]

13. Zlowocka-Perlowska, E.; Narod, S.A.; Cybulski, C. CHEK2 Alleles Predispose to Renal Cancer in Poland. JAMA Oncol. 2019, 5, 576. [CrossRef] [PubMed]

14. Siołek, M.; Cybulski, C.; Gąsior-Perczak, D.; Kowalik, A.; Kozak-Klonowska, B.; Kowalska, A.; Chłopek, M.; Kluźniak, W.; Wokołorczyk, D.; Palyga, I.; et al. CHEK2 mutations and the risk of papillary thyroid cancer. Int. J. Cancer 2015, 137, 548-552. [CrossRef]

15. Cybulski, C.; Lubiński, J.; Wokołorczyk, D.; Kuźniak, W.; Kashyap, A.; Sopik, V.; Huzarski, T.; Gronwald, J.; Byrski, T.; Szwiec, M.; et al. Mutations predisposing to breast cancer in 12 candidate genes in breast cancer patients from Poland. Clin. Genet. 2014, 88, 366-370. [CrossRef] [PubMed]

16. Cybulski, C.; Kluźniak, W.; Huzarski, T.; Wokołorczyk, D.; Kashyap, A.; Rusak, B.; Stempa, K.; Gronwald, J.; Szymiczek, A.; Bagherzadeh, M.; et al. The spectrum of mutations predisposing to familial breast cancer in Poland. Int. J. Cancer 2019, 145, 3311-3320. [CrossRef] [PubMed] 
17. Wokołorczyk, D.; Kluźniak, W.; Huzarski, T.; Gronwald, J.; Szymiczek, A.; Rusak, B.; Stempa, K.; Gliniewicz, K.; Kashyap, A.; Morawska, S.; et al. Mutations in ATM, NBN and BRCA2 predispose to aggressive prostate cancer in Poland. Int. J. Cancer 2020, 147, 2793-2800. [CrossRef]

18. National Cancer Registry—Reports [Online]. Available online: http:/ / onkologia.org.pl/raporty/ (accessed on 18 May 2021).

19. Zhang, L.; Wu, Y.; Liu, F.; Fu, L.; Tong, Z. Characteristics and survival of patients with metachronous or synchronous double primary malignancies: Breast and thyroid cancer. Oncotarget 2016, 7, 52450-52459. [CrossRef]

20. Tanaka, H.; Tsukuma, H.; Koyama, H.; Kinoshita, Y.; Kinoshita, N.; Oshima, A. Second Primary Cancers Following Breast Cancer in the Japanese Female Population. Jpn. J. Cancer Res. 2001, 92, 1-8. [CrossRef]

21. Bolf, E.L.; Sprague, B.L.; Carr, F.E. A Linkage Between Thyroid and Breast Cancer: A Common Etiology? Cancer Epidemiol. Biomark. Prev. 2019, 28, 643-649. [CrossRef]

22. Park, J.S.; Oh, K.K.; Kim, E.-K.; Chang, H.-S.; Hong, S. Sonographic Screening for Thyroid Cancer in Females Undergoing Breast Sonography. Am. J. Roentgenol. 2006, 186, 1025-1028. [CrossRef]

23. Park, C.M.; Lee, Y.D.; Oh, E.M.; Kim, K.-I.; Park, H.K.; Ko, K.-P.; Chung, Y.S. The prognosis and treatment of primary thyroid cancer occurred in breast cancer patients: Comparison with ordinary thyroid cancer. Ann. Surg. Treat. Res. 2014, 86, 169-176. [CrossRef] [PubMed] 